https:/jurnal.unigal.ac.id/index.php/jall/index

ISSN: 2598-8530

September 2018, Vol. 2 No. 2

English Education Program

Faculty of Teacher Training and Education

Galuh University

\begin{tabular}{|ccc|}
\hline Received: & Accepted: & Published: \\
\hline July 2018 & August 2018 & September 2018 \\
\hline
\end{tabular}

\title{
THE EFFECTIVENESS OF USING PADLET IN TEACHING WRITING DESCRIPTIVE TEXT
}

(A Mixed Methods at $10^{\text {th }}$ Grade of One Senior High School in Ciamis)

\section{ILHAM SUKMA TAUFIKUROHMAN}

Galuh University

aa.elhafidz@gmail.com

\begin{abstract}
This study was investigated the effects of Padlet on students' descriptive text writing of Senior High School students as well as to find out their perceptions of using Padlet for learning descriptive text writing. In doing so, the subjects consisted of 54 students who were in tenth grade. Then they were divided into two equal experimental and control groups $(\mathrm{N}=27)$. Their age ranged between 16 and 17 years old. Gender of participants was not considered as a variable in the study. This study used convergent parallel mixed-method whereas pre-test and post-test were administrated to collect quantitative data and questionnaire was given to collect qualitative data. The experimental group was taught descriptive text writing via Padlet application, whereas the control group was taught by conventional media. Analyzing the data through the independent sample t-test revealed that with the help of Padlet application, the experimental group outperformed the control group in terms of writing descriptive text. Furthermore, the students had a positive attitude toward utilization of Padlet application.
\end{abstract}

Keywords: Padlet, students, descriptive text writing

\section{INTRODUCTION}

The world today drowns us in an ocean of technological tools and gadgets. In education, without exception, technology already became a part of teaching tools as well as a support for learning. Looking closely in language learning, implementing technological tools and apps might be a good approach. (Haris et al., 2017). 
The use of technology namely social networking sites or Web 2.0 can facilitate teaching and learning. It helps average learners to learn effectively and more interactive with real time modalities depending on the learning style of the student. It is used in real life situation that incorporates in the language class (Jaganathan, 2016). Web 2.0 technologies offer a platform to establish a learning network, collaborate and share information to engage students with their learning. According to Fuchs (2014), Padlet provides a free multimedia friendly wall which can be used to encourage real-time whole class participation and assessment. Therefore, this study focused on one of Web 2.0 tools - Padlet for teaching writing descriptive text.

Writing descriptive text is one of the materials that are taught in school especially in Indonesian senior high school. However, many students face some problems in writing descriptive text. Husna et al. (2013) found that one of students' difficulties in writing descriptive text is that they are still unable to transfer and develop their idea into a written form well in composing a text. Then, students fail to show well-organized writing. They do not write a list of their ideas; they just directly wrote what they thought without planning. By this fact, the writer tries to use Padlet as a media to teach writing descriptive text.

While those researches noted the varying topics of social media Padlet in English language teaching, unfortunately, it did not focus on students' descriptive text writing ability. Thus, the purpose of this study is, therefore, to investigate how Padlet can be effective to improve students' descriptive text writing performance.

\section{An Overview of TELL (Technology-Enhanced Language Learning)}

Technology can play an important role in supporting and improving language learning. The effectiveness of each technological tool depends on the knowledge and expertise of a qualified language teacher who manages and facilitates the language learning environment. To empower, promote and disseminate language, it is important to utilize all potential mechanisms, one of which is TELL (Technology-Enhanced Language Learning) or CALL (ComputerAssisted Language Learning). Charalabopoulou (2010) argued that nowadays, 
developing materials for learning second language / foreign language (L2) within the TELL framework is a must because it not only ensures equal opportunities from all languages and cultures but also addresses the needs of people who are interested in the language but cannot attend language courses because of problems related to mobility, age, gender, financial status or just because there are no courses available around the area where they are stay. In this context, we consider TELL as a very powerful mechanism to provide easy and affordable access to foreign language education.

According to Kranthi (2017), TELL or Technology-Enhanced Language Learning deals with the impact of technology on teaching and learning a second language also called the L2. Technology-Enhanced language learning refers to the use of computer as a technological innovation to display multimedia as a means of complementing a teaching method language teacher. TELL is very supportive of Computer Mediated Communication (CMC). CMC has been researched and supported as being very useful for helping students speak and write in a foreign language which is important to teaching process using TELL. What's important to note is that TELL is not a teaching method but rather an approach that can be used alongside a teaching method to help teach.

\section{An Overview of Padlet}

There are many webs 2.0 tools such as Google+, Edmodo, Prezi and so on. For this purpose, one of these tools, Padlet, was used for this study. Padlet, is a web 2.0 tool for interaction on a virtual wall and has been used for simple instructional tasks, as well as for more complicated tasks among experts (Dewitt et al., 2017). Padlet (formerly Wall wisher) is a free application to create an online bulletin board that you can use to display information for any topic. Padlet is a very useful web tool to promote collaborative learning among our students. It's like a piece of paper, but on the Web. Padlet is a web app that lets users post notes on a digital wall. The uses for this site in the classroom are virtually endless (Jaganathan, 2016).

A Web 2.0 technology application such as Padlet can be used in a similar way to create a virtual wall, but with some significant advantages. It works across 
the world on virtually any internet-enabled device. It has permanence: the 'Walls' can be kept and can be copied. Multimedia files and documents can be posted. It can be used on a simple task such as starters and plenaries or could be used to run an entire lesson. It needs no special training and it is free. It can be used for collaborative projects such as starters, plenaries, differentiation, quizzes (Weller, 2013).

In classroom setting, Padlet works well with activities such as brainstorming, discussion and project work. Students can learn through Padlet anytime anywhere with any internet-enable devices such as smartphone, tablet, and computer with internet connection. There is no software needed to be downloaded to use Padlet. Students can then share their works on Facebook, Google+, e-mail or even embedded the URL into their blog (Haris et al., 2017).

\section{An Overview of Writing}

The main purpose of teaching English is to enable students to communicate both oral and written forms, and to understand English text. The students can learn all language skills (listening, speaking, reading and writing) and language components (grammar, pronunciation and vocabulary). Wardani et al. (2014) stated among the language skills, writing seems to be the most difficult one in the sense that it needs a long process starting from brainstorming up to final product. In addition, it involves some writing elements such as content, grammatical function, vocabulary, and the mechanics like punctuation, capitalization and spelling.

There are many different definitions about writing given by experts from many resources. Nunan (2003) said that writing can be defined by a series of contrast: it is both a physical and a mental act, its purpose is both to express and impress and it is both a process and a product writing is a media to communicate between writers and readers, writing has to be understandable so the readers will know what the researcher means clearly. Kern (2000) stated that writing is functional communication, making learners possible to create imagined worlds of their own design. Writing is the activity or occupation of writing, for example books, stories, or articles. In addition, Oshima and Hogue (2007) said that writing 
is a discovery process that involves discovering ideas, how to organize them and what that you want to put over to your order, so a lot of what a writer does as a writer doesn't actually appear on the page. It is a means of communication. Whenever the writer wants to write, he has to knowing the audience or reader, it will help in reaching the goal of communicating clearly and effectively.

From definitions above, it can be said that there are many factors influencing writing to be a good one such as grammatical, vocabularies, punctuation, and spelling knowledge which must be integrated to be a paragraph. The writer concludes that writing is more than a medium communication. It is a way of remembering and a way of thinking. Because of that, writing is not easy. It needs a hard work. In writing we have to produce words, phrase, sentences, and paragraph at the same time. It is a way of learning. None of us can write much of interest without first thinking, probing, observing, asking question, experimenting, and reading.

\section{An Overview of Teaching Writing}

Teaching English is easy, but teaching writing well is not easy. Harmer (2004) stated that there are five stages in teaching writing. They are demonstrating, motivating and provoking, supporting, responding, and evaluating. In the first stage is demonstrating. In these stages, the teachers give examples about text to the students. It includes the purpose of the text, the social function of the text, grammatical features of the text, and generic structure of the text. The second stage was motivating and provoking. Before the teachers enter to the material in writing, they must prepare the media to stimulate the students' brain in generating ideas. It can use pictures or another media. Then, the next stage is supporting.

Actually, the teachers need to help students. They should be a valuable anytime to give feedback to the students' works. They must try to help students to solve the students' problems in writing. After then, it is responding stage. The teachers give some suggestion to the students' works. They must give comment, correction, and suggestion in the students' works. And the last stage is evaluating. In these stages, the teachers judge the students' works as the final product. From 
the evaluation, the teacher could get the students' writing score. Harmer (2004) also stated that the students should pay attention not only in what they are going to write but also how they are going to write. There are some strategies in teaching writing.

\section{An Overview of Descriptive Text}

Descriptive text is a text which is intended to describe a particular person, place or thing. According to Oshima and Hogue (2007), descriptive writing appeals to the senses, so it tells how something looks, feels, smells, tastes, and or sounds. In addition, a good description is like a "word picture"; the reader can imagine the object, place, or person in his or her mind. A writer of a good description is like an artist who paints a picture that can be "seen" clearly in the mind of the reader.

Descriptive text is a kind of writing that involves not so much telling the readers about facts or events as showing the readers something (Emilia, 2008). It has many valuable uses in other kinds of writing. In Descriptive text, writers describe person, object, appearances, landscape or phenomenon naturally so they can make the reader imagine and feel it (Alwasilah, 2007). When describing someone or something, the writer should give the readers a picture in words. To make writing as real, the writer must write a specific detail to appeal the reader's senses. As Langan (2001) stated that to make the word picture as vivid and real as possible, the writer must observe and record specific details that appeal to reader's senses. Furthermore, he said that a descriptive writing is different from other type of essay because it needs sharp and colorful details.

As social beings, people need to share their experience, so they write to others to describe things such as vacations, childhood homes, and people they encounter. Based on the explain of Fine (2002), the purposes of descriptive text are to entertain, to express feelings, to relate experience, to inform a reader which unfamiliar with the subject or create a fresh appreciation for the familiar, and to persuade the reader. 


\section{METHOD}

Dealing with research questions that had been proposed by the writer, in this study, the writer used Convergent Parallel Mixed Methods Design as the main design of this study (Creswell, 2014). By using Convergent Parallel Mixed Methods Design, the qualitative method was used to obtain data or information from the results of experimental application of Using Padlet in Improving Students' descriptive text writing. While qualitative method was used to understand the relation between results obtained by student after treatment. The selection of Convergent Parallel Mixed Methods Design was based on the opinion of Creswell (2014) which convey that in this approach, the writer collected both quantitative and qualitative data during the experimental study, the two data analyzed separately, and the two data was used to answer different research questions. In the research of the explanatory design, the writer gave priority to the collection of quantitative data and collection of qualitative data. In addition, the writer used quasi-experimental design to experimental design.

\section{Population and Sample}

Population is an entire group of people of subject or event which all have at least one characteristic in common, and must be defined specifically and unambiguously as defined by Burns (2000). In this study, the population of the study includes all the tenth-grade of the one senior high school in Ciamis in the academic year 2017/2018 which consisted of 11 classes.

Fraenkel et al. (2012) stated that cluster random sampling is the selection of groups, or cluster, of subjects rather than individuals. In this case, the writer took two classes in order to get the data. In this case, the writer took the students at class X-MIA 2 and class X-MIA 5. The total number of the sample are 54 students.

\section{Data Collection}

In collecting quantitative data, the writer used pre-test and post-test as research instruments to collect the data. In addition, Brown (2001) stated that a test is method of measuring person's ability or knowledge in a given domain. 
Based on the statement above, the writer used written test to measure the ability of students' descriptive text writing. The students made a descriptive text by following its generic structure. Those are identification and description. They also used the language features of descriptive text such as using simple present tense, action verbs, passive voice, noun phrase, adverbial phrase, technical terms, general and abstract noun, and conjunction of time and cause-effect. Moreover, in collecting data for qualitative, the writer used questionnaire to students. The closeended questionnaire was used in this research. For the form of questionnaire, the writer gave some statements.

\section{Data Analysis Technique}

In the process of data gathering, the writer used the students' score pre-test and post-test. To analyze the data, the writer used the following computation of statistics which is adapted from (Burns, 2000) as follows:

$$
t=\frac{m_{1}-m_{2}}{\sqrt{\frac{\left[\sum x_{1}^{2}-\frac{\left(\sum x_{1}\right)^{2}}{n_{1}}\right]}{\left(n_{1}-1\right)}+\frac{\left[\sum x_{2}^{2}-\frac{\left(\sum x_{2}\right)^{2}}{n_{2}}\right]}{\left(n_{2}-1\right)}\left(\frac{1}{n_{1}}+\frac{1}{n_{2}}\right)}}
$$

In analyzing the data from qualitative result, the writer used descriptive statistic which was adapted from Fraenkel and Wallen (2012). The writer choose questionnaire because by using questionnaire students were able to freely write down the things they really felt. A questionnaire is a written collection of selfreport questions to be answered by a selected group of research participants (Gay, Mills, and Airasian, 2012).

\section{FINDINGS AND DISCUSSION}

This regard attempted to analyze the effectiveness of using Padlet on students' descriptive text writing performance at tenth grade of one Senior High School in Ciamis. The first purpose of this research is to find out the effectiveness of using Padlet on students' performance in writing descriptive text. The design of the research that used by the writer was quasi-experimental design and it was conducted to test hypothesis. Furthermore, writing descriptive test was used as a 
research instrument in this research. Students were asked to write descriptive text minimally two paragraphs as material in Oshima and Hogue (2007). In scoring the test, the writer analyzed their work by using form of Brown (2007). In addition, the data that had been obtained from writing test was analyzed and evaluated by using t-observed formula taken from Burns (2000). The findings are as follows:

Table 1. The findings of data computation

\begin{tabular}{|l|l|c|}
\hline 1. & The mean difference of experimental group & 0,9 \\
\hline 2. & The mean difference of control group & 0,6 \\
\hline 3. & Gained score of experimental group & 26 \\
\hline 4. & Gained score of control group & 18 \\
\hline 5. & t-observed & 3 \\
\hline 6. & Degree of freedom (df) & 52 \\
\hline 7. & t-table & 2,000 \\
\hline
\end{tabular}

Based on the findings of statistical computation, the t-observed value was 3 and t-critical value was 2,000. It means that -observed value was higher than tcritical value. So, the null hypothesis $\left(\mathrm{H}_{0}\right)$ was rejected and the alternative hypothesis $\left(\mathrm{H}_{1}\right)$ was accepted. In conclusion, there is a significant difference of students' descriptive text writing between students who are taught by Padlet and those who are not. In relating to this study, students' thinking skills were increasing especially in students' descriptive text writing skills. It can be seen from the quantitative findings of this study.

\section{The students' perceptions of teaching writing descriptive text by using Padlet}

In this section, to answer the second research question concerning What are the students' perceptions of teaching writing descriptive text by using Padlet? the writer conducted questionnaire to collect the data to 27 students by using a brief rating scales questionnaire such as strongly agree, agree, neutral, disagree and strongly disagree. In collecting the data, the writer adapted questionnaire from Martin (2005). The presentation of data used a formula from Fraenkel and Wallen 
(2012). After that, the writer discussed point by point from the table of questionnaire. The data of questionnaires can be seen in the table below:

Table 2. The respondent responded towards statement 1

\begin{tabular}{|c|l|c|c|c|c|l|}
\hline No & \multicolumn{1}{|c|}{ Statement } & SA & A & NT & D & SD \\
\hline 1. & $\begin{array}{l}\text { Padlet is interesting for me to write } \\
\text { descriptive text }\end{array}$ & 13 & 13 & 1 & 0 & 0 \\
\hline
\end{tabular}

The table showed that most students answered strongly agree and also agreed that they were interested in writing descriptive text using the media Padlet. It can be demonstrated by the same frequency between those who strongly agree and agree with this statement. The total number of scores was 13 of 27 students with a percentage of $48.1 \%$ of total responses.

Table 3. The respondent responded towards statement 2

\begin{tabular}{|c|l|c|c|c|c|c|}
\hline No & \multicolumn{1}{|c|}{ Statement } & SA & A & NT & D & SD \\
\hline 2. & $\begin{array}{l}\text { Padlet is comfortable for me in learning } \\
\text { process }\end{array}$ & 5 & 21 & 1 & 0 & 0 \\
\hline
\end{tabular}

Based on data from table 3, it showed that most of the students answered agree with the statement of whether they felt comfortable or not while writing descriptive text using Padlet. It could be seen that the frequency was 21 out of 27 students with a percentage $77.7 \%$ of total responses.

Table 4. The respondent responded towards statement 3

\begin{tabular}{|c|l|c|c|c|c|c|}
\hline No & \multicolumn{1}{|c|}{ Statement } & SA & A & NT & D & SD \\
\hline 3. & $\begin{array}{l}\text { Padlet gives me more attention in learning } \\
\text { process }\end{array}$ & 10 & 16 & 1 & 0 & 0 \\
\hline
\end{tabular}

Regarding on data from table 4, it was understandable that most students answered agree with the statement. After studying descriptive texts using Padlet, they were able to pay more attention to the learning process. From these data, it 
can be seen that the frequency was 16 of 27 students with a percentage of $59.2 \%$ of the total responses.

Table 5. The respondent responded towards statement 4

\begin{tabular}{|r|l|l|l|l|l|l|}
\hline No & \multicolumn{1}{|c|}{ Statement } & SA & A & NT & D & SD \\
\hline 4. & $\begin{array}{l}\text { Padlet motivates me more for studying in } \\
\text { classroom }\end{array}$ & 8 & 17 & 2 & 0 & 0 \\
\hline
\end{tabular}

Based on data from table 5, it was understandable that most students answered agree with the statement. They answered that after learning descriptive texts using Padlet platform, they were more motivated in the learning process. From these data it can be seen that the frequency was 17 out of 27 students with a percentage of $63 \%$ of the total responses.

Table 6. The respondent responded towards statement 5

\begin{tabular}{|l|l|l|l|l|l|l|}
\hline No & \multicolumn{1}{|c|}{ Statement } & SA & A & NT & D & SD \\
\hline 5. & $\begin{array}{l}\text { Padlet is easy for me and learning process } \\
\text { become more organized in classroom }\end{array}$ & 13 & 12 & 1 & 1 & 0 \\
\hline
\end{tabular}

Based on data from table 6, it can be seen that most of the students answered strongly agree with the statement and the frequency was 13 of 27 students. They replied that the Padlet was easy for them and the learning process became more organized in the classroom. The percentage of students who voted for this statement was $44.3 \%$ of the total responses.

Table 7. The respondent responded towards statement 6

\begin{tabular}{|l|l|l|l|l|l|l|}
\hline No & \multicolumn{1}{|c|}{ Statement } & SA & A & NT & D & SD \\
\hline 6. & $\begin{array}{l}\text { Padlet gains me more material about } \\
\text { writing descriptive text }\end{array}$ & 17 & 7 & 1 & 2 & 0 \\
\hline
\end{tabular}

Based on data from table 7, it can be seen that most students answered strongly agree with the statement. They answered that after learning descriptive texts using 
Padlet, they got more material about writing descriptive texts. From these data, the frequency of students who answered strongly agree with the statement was 17 of 27 students and the percentage was $62.9 \%$ of the total responses.

Table 8. The respondent responded towards statement 7

\begin{tabular}{|l|l|l|l|l|l|l|}
\hline No & \multicolumn{1}{|c|}{ Statement } & SA & A & NT & D & SD \\
\hline 7. & $\begin{array}{l}\text { Padlet give me a guidance to write } \\
\text { descriptive text }\end{array}$ & 5 & 21 & 1 & 0 & 0 \\
\hline
\end{tabular}

Based on data from table 8, it showed that most students answered agree with the statement. They answered that after writing a descriptive text using Padlet, it could provide guidance in writing descriptive text. From the data, it can be seen that the frequency was 21 of the 27 students agree with this statement and the percentage was $77.7 \%$ of the total responses.

Table 9. The respondent responded towards statement 8

\begin{tabular}{|c|c|c|c|c|c|c|}
\hline No & Statement & SA & A & NT & D & SD \\
\hline 8. & Padlet helps me in learning achievement & 7 & 16 & 3 & 1 & 0 \\
\hline
\end{tabular}

Based on data from table 9, it showed that 16 out of 27 students answered agree with the statement. They answered that after studying descriptive texts using Padlet, it helped them in learning achievement and the percentage was 59.2\%.

Table 10. The respondent responded towards statement 9

\begin{tabular}{|c|l|c|c|c|c|c|}
\hline No & \multicolumn{1}{|c|}{ Statement } & SA & A & NT & D & SD \\
\hline 9. & $\begin{array}{l}\text { Padlet makes learning time become } \\
\text { narrower }\end{array}$ & 1 & 8 & 3 & 11 & 4 \\
\hline
\end{tabular}

Based on data from table 10, the results showed that most students answered that they did not agree with the statement. They replied that after studying descriptive texts using Padlet, it did not make the learning process narrower. From the data, it can be understood that the frequency was 11 out of 27 total students who disagree with the statement and the percentage was $40.7 \%$ of the total responses. 
Table 11. The respondent responded towards statement 10

\begin{tabular}{|r|l|l|l|l|l|l|}
\hline No & \multicolumn{1}{|c|}{ Statement } & SA & A & NT & D & SD \\
\hline 10. & $\begin{array}{l}\text { Padlet is not affective because lack of } \\
\text { interaction between students and instructor }\end{array}$ & 1 & 7 & 3 & 8 & 8 \\
\hline
\end{tabular}

Based on data from table 11 , it showed that there were similar results in the number of students between who disagree and strongly disagree. Each got a frequency of 8 out of 27 students with a percentage of $29.6 \%$ respectively.

Table 12. The respondent responded towards statement 11

\begin{tabular}{|r|l|l|l|l|l|l|}
\hline No & \multicolumn{1}{|c|}{ Statement } & SA & A & NT & D & SD \\
\hline 11. & $\begin{array}{l}\text { Padlet makes the material unpresented well } \\
\text { by teacher }\end{array}$ & 0 & 9 & 5 & 3 & 10 \\
\hline
\end{tabular}

Based on data from table 12, it showed that most of the students answered strongly disagree with the statement. They answered that when writing descriptive texts using Padlet, the material could still be presented properly by the teacher. From these data, it could be seen that the frequency was 10 of 27 students strongly disagree with the statement and the percentage was $37.1 \%$ of the total responses.

Table 13. The respondent responded towards statement 12

\begin{tabular}{|r|l|l|l|l|l|l|}
\hline No & \multicolumn{1}{|c|}{ Statement } & SA & A & NT & D & SD \\
\hline 12. & $\begin{array}{l}\text { Padlet requires good smartphone to be used } \\
\text { in classroom }\end{array}$ & 14 & 9 & 3 & 1 & 0 \\
\hline
\end{tabular}

Based on data from table 13, it provided information that most students answered strongly agree with the statement. They answered that when using Padlet as a media in writing descriptive text, it required a smartphone with good specifications to be used in the learning process. As a result, 14 of the 27 students answered strongly agree with the statement with a percentage of $51.8 \%$ of the total responses. 
Table 14. The respondent responded towards statement 13

\begin{tabular}{|r|l|l|l|l|l|l|}
\hline No & \multicolumn{1}{|c|}{ Statement } & SA & A & NT & D & SD \\
\hline 13. & $\begin{array}{l}\text { Padlet requires stable internet connection to } \\
\text { be used in classroom }\end{array}$ & 15 & 9 & 1 & 0 & 2 \\
\hline
\end{tabular}

Based on data from table 14, it showed that most of the students answered strongly agree with the statement. They answered that to write descriptive text using Padlet, a stable internet connection was required for using the smartphone in the classroom. From the data, it could be seen that the frequency was 15 of the 27 students strongly agree with this statement and the percentage was $55.5 \%$ of the total responses.

Table 15. The respondent responded towards statement 14

\begin{tabular}{|r|l|l|l|l|l|l|}
\hline No & \multicolumn{1}{|c|}{ Statement } & SA & A & NT & D & SD \\
\hline 14. & $\begin{array}{l}\text { Writing descriptive text by using Padlet is } \\
\text { difficult for me than without Padlet }\end{array}$ & 1 & 5 & 7 & 12 & 2 \\
\hline
\end{tabular}

Based on data from table 15, it showed that most of the students answered disagree with the statement. They did not agree that writing descriptive text using Padlet was difficult for them than without Padlet. From the data, it could be seen that the frequency was 12 of the 27 students answered disagree with the percentage of $44.4 \%$ of the total responses.

Table 16. The respondent responded towards statement 15

\begin{tabular}{|r|l|l|l|l|l|l|}
\hline No & Statement & SA & A & NT & D & SD \\
\hline 15. & Padlet is very costly for me & 2 & 12 & 5 & 7 & 1 \\
\hline
\end{tabular}

Based on data from table 4.22 and 4.7 , it showed that most students answered agree with the statement. They answered that to write descriptive texts using Padlet, it was quite expensive for them. From the data, it could be seen that the 
frequency was 12 out of 27 students agree with the statement and the percentage was $44.4 \%$ of the total responses.

According to obtained findings from each questionnaire response, the writer concluded that students' perception of the use of Padlet in developing students' descriptive text writing had influence in their descriptive text writing ability. Therefore, students responded that they had positive perception of using Padlet in their descriptive text writing. Related to the findings of the study, the students seemed to find Padlet a suitable tool for learning. They were interested in seeing their friends' comments, and sharing on the platform. This was perhaps due to the fact that the tool was easy to use. As Jaganathan (2016) stated that Padlet helps in giving students an enriching writing experience through. Padlet provides students a platform for sharing their writing with teachers and peers. Additionally, Wood (2016) stated that Padlet can also be an "exit ticket" or interactive assessment tool to use in the classroom instead of the traditional (yet sometimes boring) pen and paper.

According to research finding, the writer found significant difference in teaching descriptive text to EFL students in one of Senior High School in Ciamis between who are taught by using Padlet and those who are not. Moreover, it can be seen that Padlet can develop students' descriptive text writing ability. This study was in line with the study from Haris et al. (2017) conducted the research entitled "The Effectiveness of Using Padlet in ESL Classroom". The findings indicated that the use of Padlet is effective in enhancing students ${ }^{\text {ee }}$ performance in language learning. In answering the second question, the writer administrated the questionnaire to find out students' perception on teaching descriptive text by using Padlet application. Students responded that they had positive perception of using Padlet in their descriptive text writing. this study also was in line with the study from Fuchs (2014) conducted the research entitled "The Writing is on the Wall: Using Padlet for Whole-Class Engagement". The result of this study revealed that using Padlet in instruction has provided a non-threatening space for the collection and curation of collaborative classroom work. All students have the 
ability to contribute and learn from one another and all voices can be heard on a graffiti wall.

\section{CONCLUSIONS}

After completing this research, the writer concludes that Padlet can give contribution in students' descriptive text writing mastery in tenth grade of one Senior High School in Ciamis. From the statistical computation, it can be concluded that the value of t-test (3) is higher than the value of t-table $(2,000)$. Therefore, it can be concluded that there is a significant difference in students' descriptive text writing ability between those who are taught by Padlet and those who are not. In answering the second research questions, the writer concluded that students' perception of the use of Padlet in developing students' descriptive text writing had influence in their descriptive text writing ability. Therefore, students responded that they had positive perception of using Padlet in their descriptive text writing.

\section{REFERENCES}

Alwasilah, A. C. (2007). Pokoknya Menulis. Bandung: Kiblat.

Blanchard, K. \& Root, C. (2003). Ready to Write ( $3^{\text {rd }}$ Ed). New York: Pearson Education, Inc.

Brown, H. D. (2007). Teaching by Principles: An Interactive Approach to Language Pedagogy. (2nd ed.). New York: Longman.

Burns, R.B. (2000). Introduction to Research Methods (4th Ed). London: Sage.

Charalabopoulou, F. (2010). TELL (Technology-Enhanced Language Learning) and Less-Commonly Taught Languages: The Case of Modern Greek. Technology Enhanced Learning, 156-163. Athens: Springer.

Clouse, B.F. (2004). The Student Write. New York: McGraw-Hill Companies, Inc.

Cresswell, J.W. (2012). Educational Research: Planning, Conducting and Evaluating Quantitative and Qualitative Research $\left(4^{\text {th }} E d\right)$. Boston: Pearson Education, Inc. 
Dewitt, D., Alias, N., \& Siraj, S. (2015). Collaborative Learning: Interactive Debates Using Padlet in a Higher Education Institution. Procedia - Social and Behavioral Sciences, 176, 220-226. Kuala Lumpur.

Emilia, E. (2008). Teaching writing. Developing critical learners. Bandung: Rizki Press.

Fraenkel, J. R., Wallen, N. E. \& Hyun, H. H. (2012). How to Design and Evaluate Research in Education $\left(8^{\text {th }} E d\right)$. New York: Mc. Graw-Hill Inc.

Fuchs, B. (2014). The Writing is on the Wall: Using Padlet for Whole-Class Engagement. LOEX Quarterly. 40 (4). 7-9. Kentucky.

Gay, L. R., Mills, G. E. \& Airasian, P. W. (2012) Educational Research: Competencies for Analysis and Application (10th Edition). New Jersey: Pearson Education, Inc.

Haris, M., Yunus, M \& Badusah, J. (2017). The Effectiveness of Using Padlet in ESL Classroom. International Journal of Advanced Research (IJAR). 5(2). 783-788. Selangor.

Harmer, J. (2004). How to Teach Writing. England: Pearson Education Ltd.

Husna, L., Zainil, Rozimela, Y. (2013). An Analysis of Students' Writing Skill in Descriptive Text at Grade XI IPA 1 of MAN 2 Padang. Journal English Language Teaching. 1(2)

Jaganathan, S. (2016). Edmodo and Padlet as a Collaborative Online Tool in Enriching Writing Skills in Language Learning and Teaching. Global English-Oriented Research Journal (G E O R J), 1(4). Namakkal.

Kern, R. (2000). Literacy and Language Teaching. New York: Oxford University Press.

Kistono. (2006). Sma Kl.10 The Bridge English Competence. Jakarta: Yudhistira.

Kranthi, K. (2017). Technology Enhanced Language Learning (TELL). International Journal of Business and Management Invention, 6 (2), 30-33. Hyderabad.

Langan, J. (2001). College Writing Skills with Readings. New York: McGraw-Hill Inc.

Lee, M. J. W. \& McLoughlin, C. (2011). Web 2.0-Based E-Learning: Applying Social Informatics for Tertiary Teaching. New York: IGI Global. 
Martin, M. (2005). Seeing is Believing: The Role of Videoconferencing in Distance Learning. British Journal of Educational Technology, 36 (3), 397405. Tyrone.

Nunan, D. (2003). Practical English Language Teaching. New York: The McGraw Hill.

Oshima, A. \& Hogue, A. (2007). Introduction to Academic Writing (3rd Edition). New York: Pearson Education, Inc.

Ur, P. (1996). A Course in Language Teaching: Practice and Theory. London: Cambridge University Press.

Wardani, I., Basri, H., Waris, A. (2014). Improving the Ability in Writing Descriptive Text Through Guided-Questions Technique. e-Journal of English Language Teaching Society (ELTS). 2 (1). 2331-1841. Palu.

Weller, A. (2013). The Use of Web 2.0 Technology for Pre-Service Teacher Learning in Science Education. Research in Teacher Education, 3(2), 40-46. London.

Wood, M. (2016). Padlet a Graffiti Wall for Today's Agricultural Teacher. The Agricultural Education Magazine. 20-26. Kentucky. 